\section{Gal eller ikke gal?}

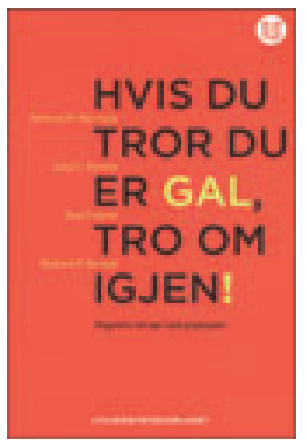

Anthony P. Morrison, Richard P. Bentall, Paul French et al.

Hvis du tror du er gal, tro om igjen!

Kognitiv terapi ved psykoser. 148 s, tab. ill.

Oslo: Universitetsforlaget, 2011. Pris NOK 259 ISBN 978-82-15-01561-3

Forfatterne gjør helhjertede forsøk på å avdramatisere, til dels normalisere psykosetilstander. De skal krediteres for at de kommer en pasientgruppe i møte som først $\mathrm{i}$ den senere tid har fanget interesse innenfor psykologi og psykiatri. Denne store og heterogene pasientgruppen blir oppvurdert som kompetent på sin egen tilstand, noe som bidrar positivt i tidens trend med økt vekt på brukermedvirkning.

Men boken har en del svakheter. Leseren overlesses med prosenter og antall briter og amerikanere som har opplevd psykosenære fenomener, i en grad som blir kjedelig oppramsing av angivelig dokumenterte fakta. Noen av referansene virker troverdige, andre ikke. Når forfatterne hevder (s. 17) at «En rekke studier viser», uten henvisning til referanser, gir det et uheldig inntrykk. Ved å søke i Ovid/Medline på kombinasjonen «psychosis» og «cognitive therapy» oppnås 272 treff. Til sammenlikning har denne boken 32 referanser. Enkelte eksempler på glidende overganger mellom normalitet og psykose virker ikke adekvate. Forfatterne hevder f.eks. at det kan være en form for hørselshallusinose når man går og nynner på en melodi som man ikke kan få ut av hodet.

Utgivelsen lanseres som en selvhjelpsbok med flere egenutfyllingsskjemaer. Det ville gitt boken mer troverdighet og faglig forankring dersom forfatterne hadde poengtert at å bruke slike skjemaer bør foregå i tett samarbeid med en terapeut for å sette innholdet i en trygg ramme. Det anføres noen få steder i de to gjennomgående kasuistikkene at pasienten diskuterte sine opplevelser med en terapeut, men dette burde vært mye mer fremhevet.

Forfatterne gir ingen form for differensiering av psykotiske tilstander med eventuelle forskjeller i prosedyrer og hensiktsmessig bruk av selvutfyllingsskjemaer, selv om de to kasuistikkene riktignok omhandler forskjellige alvorlighetsgrader i symptomer (spesielt paranoiditet) og funksjonsnivå.

På omslaget angir forlaget at boken er skrevet av «internasjonalt anerkjente fagpersoner innen psykosefeltet og kognitiv terapi». En mer omfattende presentasjon av forfatterne hadde vært på sin plass - slik at leserne ikke blir sittende igjen med spørsmål om deres profesjon og kliniske erfaring.

Av de 12 kapitlene kan kapittel 10 om medisinbruk fremheves. Her gir forfatterne en historisk oversikt over utviklingen av psykofarmaka, og fremstillingen virker saklig når de påpeker at medikamenter er nødvendig som et bidrag i et omfattende terapiopplegg. Utsagnene «Vårt eget syn er at medikamentell behandling er til stor hjelp for noen mennesker og til skade for andre» (s. 98) og «selv om det er vanskelig å anslå, har ca. $70 \%$ av pasientene nytte av denne behandlingen (antipsykotika)» (s. 104) er mer balanserte enn det man kan finne i annen litteratur om temaet.

Boken er lettlest, har en god layout, og de to kliniske kasuistikkene er instruktive. For terapeuter med psykotiske pasienter kan den gi nyttige impulser til variasjon i tilnærmingen til denne gruppen.

\section{Tore Gude}

Modum Bad

og

Avdeling for atferdsfag

Universitetet i Oslo

\section{De genfundne bogstaver}

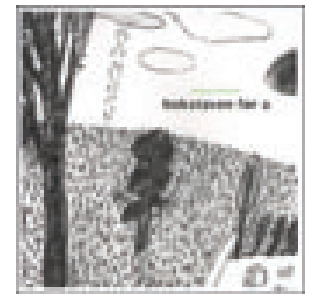

Reidun Iversen

Bokstaven før a

99 s, ill. Oslo: Alm Forlag, 2011. Pris NOK 220

ISBN 978-82-998522-0-3

Denne bog har som emne forfatterens selvoplevede kamp for at genvinde livsviljen og -evnen efter en stor sorg, af en styrke som den danske digter Steen Steensen Blicher (1782-1848) brugte som bærende sproglig vignet i novellen Hosekrcemmeren: «Den største sorg i verden her/Er dog at miste den, man har kær.»

Emnet behandles suverænt gennem kortprosatekster og forfatterens tegninger. Sammen opnår de to kunstformer at belyse en stor sorg eksistentielt, så noget personligt oplevet bliver gjort alment, og dermed skaber en potentiel stor målgruppe, for hvem tab og sorg er tilværelsens fælles grundvilkår.

Forfatterens egen titel, Bokstaven før $a$, henviser gennem billedteksterne, hvor lang vejen har været fra den sorgfremkaldte dysgrafi og dens skift fra al-fabét til «non-fabét», for at ende ved bogstavernes genvundne stilformer. Meget elegant er tekst og billeders udtryk for forfatterens brug af Bibelens formulering om kristendommens «I begyndelsen var ordet---». Først som en negation, men da livshåbet og den forsigtige livsglæde vender tilbage, bliver det en nyvunden bekræftelse ved omtalen af altergangen i den lokale landsbykirke. Her får termen «Ordet» også sin dybere mening tilbage, væk fra at være et lingvistisk-teknisk overbegreb og til betydningen «Budskabet».

Bogen igennem er forfatterens mentale overlevelse stimuleret af det nævnte «non-fabét», som er sansninger og følelser fra «da du og jeg blev vi». Det er fjeldnaturens dyrelyde og kontrasterende stilhed. Det er også lysets store variationer, årstidernes skiften, bondemadens tidløse kvaliteter, og endog barokmusikken i Bach's værker, der som i forfatterens egne blandede udtryksformer rummer store muligheder for at føre sorgens afmagt tilbage til livets egne perspektiver. Som læser inddrages man af forfatteren som fortolkende «medarbejder». Så når én af tegningerne viser en sort tavle og en kridttekst: «Skriftens engel har kun én vinge» forledes man kærligt til at koble dette udsagn til Bach's nævnte Johannespassion og tilføje: «Men når Bach samtidig udtrykker sig musikalsk, er resultatet to vinger».

Forfatterens seje arbejde med at genvinde bogstaverne begynder med at se bogstaver overalt i naturen, nåletræsbogstaver på frostsneen, rimfrostens kalligrafi, og en stankelbensskrift som flyver ud i anonymiteten. Senere beskrives sejren gennem virkeligheden: tretten selvskrevne a-er, «vakkelvorne, som det var første gang, de var ude på et papir».

Igennem tekststykkerne ses også kærlige og fine henvisninger til de fire års kærlighed, som parret fik lov at opleve. Da vårsmeltningen af sneen i deres oprindelige, fælles skispor nævnes, har kærlighedserindringen denne form: Om en uge eller to er de væk, «sporene af dine ski under mine ski». Men kærligheden smelter ikke, så et af de sidste prosabidrag er fire ord på i alt to sider med tulipaner og en mariehøne: «I morges sang jeg!»

Bogen er en gave til mennesker, som har livets opmærksomhed for kærlighed, tab og sorg, men også til alle, som fagligt møder medmennesker i eksistentielle situationer.

\section{Povl Riis}

EEldreForum

Odense

Danmark 